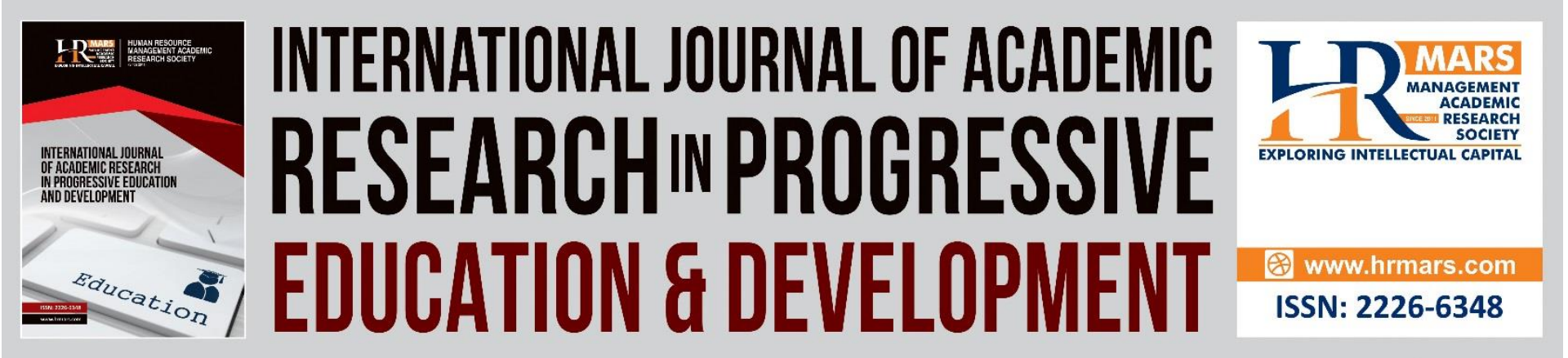

\title{
The Development and Evaluation of Augmented Reality Learning Application in Geometry Topic
}

Mohamad Basri Nadzeri, Chew Cheng Meng, Irwan Mahazir Ismail, Abd Hadi Abu Hassan

To Link this Article: http://dx.doi.org/10.6007/IJARPED/v11-i1/12279

DOI:10.6007/IJARPED/v11-i1/12279

Received: 09 November 2021, Revised: 14 December 2021, Accepted: 30 December 2021

Published Online: 16 January 2022

In-Text Citation: (Nadzeri et al., 2022)

To Cite this Article: Nadzeri, M. B., Meng, C. C., Ismail, I. M., \& Hassan, A. H. A. (2022). The Development and Evaluation of Augmented Reality Learning Application in Geometry Topic. International Journal of Academic Research in Progressive Education and Development, 11(1), 785-792.

Copyright: @ 2022 The Author(s)

Published by Human Resource Management Academic Research Society (www.hrmars.com)

This article is published under the Creative Commons Attribution (CC BY 4.0) license. Anyone may reproduce, distribute, translate and create derivative works of this article (for both commercial and non-commercial purposes), subject to full attribution to the original publication and authors. The full terms of this license may be seen at: http://creativecommons.org/licences/by/4.0/legalcode

Vol. 11(1) 2022, Pg. 785 - 792

http://hrmars.com/index.php/pages/detail/IJARPED

JOURNAL HOMEPAGE

Full Terms \& Conditions of access and use can be found at http://hrmars.com/index.php/pages/detail/publication-ethics 


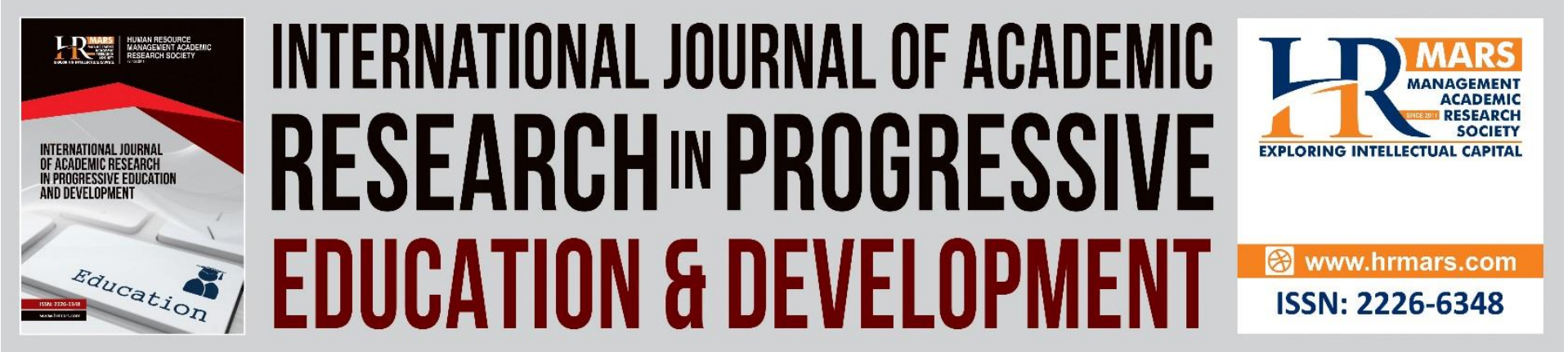

\title{
The Development and Evaluation of Augmented Reality Learning Application in Geometry Topic
}

\author{
Mohamad Basri Nadzeri ${ }^{1}$, Chew Cheng Meng ${ }^{2}$, Irwan Mahazir \\ Ismail ${ }^{3}$, Abd Hadi Abu Hassan ${ }^{4}$ \\ ${ }^{124}$ School of Educational Studies, ${ }^{3}$ Centre for Instructional Technology and Multimedia \\ Universiti Sains Malaysia \\ Email: baszeri12@gmail.com,cmchew@usm.my,irwan_mahazir@usm.my, \\ abdulhadihassan04@yahoo.com
}

\begin{abstract}
The application of technology should be applied by teachers and pupils to be prepared with knowledge and skills that can provide positive impact in teaching and learning. Hence, the Malaysia Education Blueprint 2013-2025 was developed by the Ministry of Education which emphasizes on the use of technology and innovation that can improve the achievement of students. Pupils in primary school face difficulties in basic concepts, reasoning and problem solving in geometry. Based on the global benchmarking of Trends in International Mathematics and Science Study (TIMSS) test report in 2019, the average score of mathematics achievement for Malaysian students is at a low level compared to other Southeast Asian countries like Singapore which are at the highest-level score in the world. Moreover, geometry domains also reported as low levels from 2007 to 2019. Most of teachers use drawings on whiteboards, static images in books and verbal explaining to describe threedimensional shapes to pupils. In this regard, the innovation of learning application utilizing Augmented Reality technology was developed for pupils. This study used ADDIE's instructional design model as a framework to develop the application. This study used three experts' interviews to confirm the need for developing this application and quasi experimental to evaluate the effectiveness of the application to 30 grade 2 pupils. This study is hoped that the AR technology applied can improve the effectiveness of learning, increase motivation and creative thinking skills of students in solving problems especially in geometry topic.
\end{abstract}

Keywords: Geometry, ADDIE, Augmented Reality

\section{Introduction}

Globally, technology has advanced at a breakneck pace, influencing the transformation of education in Malaysia. Therefore, the Malaysia Education Blueprint (2013-2025) focuses on the seventh shift, leveraging on education technology to improve the quality of learning in Malaysia. In fact, the primary school mathematics education curriculum also focuses on aspects of creativity and innovation, along with information technology and communication 
elements, so that students become creative, teaching and learning become more engaging, and improving students' understanding (KPM, 2017). In addition, the application of technology in teaching and learning can create a conducive learning environment, fun, encourage high level learning as well as master the basic digital skills among students starting from the low level (Outhwaite et al., 2017).

In line with the development of technology, mathematics education has also received its effects. Primary school mathematics education is aimed pupils to master the basic mathematics skills and concepts of mathematics. Pupils need to master's in mathematics since primary level to prevent difficulties in secondary school onwards. Content, pedagogy, and teaching design integrated with technology should be planned by teachers to produce fun teaching and learning in the classroom (Law \& Rosli, 2020). However, previous studies have found that low visual skills are the major factor influencing the understanding of geometry concepts for grade 2 students especially in understanding the basic concepts of 3D shape characteristics (Berna, 2014; Gunčaga \& Žilková, 2019; Ibili et al., 2019).

One of the technologies that can be applied in teaching and learning geometry is Augmented Reality (AR). AR technology allows users to interact with virtual objects that are integrated into the physical world and appear in the same space and in real time (Azuma, 1997). AR technology is also classified as a technology combined with multimedia elements such as three-dimensional animation (3D), image, graphic, audio and video via camera available on devices such as tablets, iPad, smartphones, laptops, and computers (Li et al., 2019). Various past studies in AR were conducted by researchers on the advantages in education (Sirakaya \& Sikaraya, 2020). Among the benefits in AR is that teaching, and learning become more easier in understanding abstract concepts (Akçayir et al., 2016). Next, AR can also attract students' attention to teacher teaching (Bressler \& Bodzin, 2013) and increase motivation (Chang \& Hwang, 2018; Ibanez et al., 2015). Moreover, learning through AR technology can attract and delight pupils (Gün \& Atasoy, 2017) as well as improve spatial visualization capabilities (Lin et al., 2015).

\section{Augmented Reality (AR)}

Augmented Reality is a technology that combines virtual information with the real world (Chen et al., 2019). In this context, 3-D virtual objects which is the geometry shapes combined with a 3-D real environment. Virtual and real geometry shapes appear together in a real time system in a way that the user sees the real world and the virtual objects superimposed with the real objects. The user's perception of the real world is enhanced, and the user interacts in a more natural way. The virtual objects can be used to display additional information about the real world that are not directly perceived. Milgram and Kishino (1994) introduced the concept of a Virtuality Continuum classifying the different ways that virtual and real objects can be realized. In this taxonomy scheme, Augmented Reality is closer to the real world. Azuma (1997) defines AR systems as those that have three characteristics which are combining real and virtual, interactive in real time and registered in 3D. In general, $A R$ applications fall in two categories: (i) Marker-based AR and (ii) Marker less-based AR.

Marker-based AR requires a specific marker or label to register the position of a $3 D$ virtual object to be displayed in a real-world environment. Hardware such as mobile device cameras and markers or labels in the form of QR codes are commonly used in marker-based AR applications. Image recognition is based on where the marker is placed on the screen display. Next, it will produce a matching 3D version of the image that can be rotated. Thus, the user can view the object in more detail and various angles. Next, marker less-based AR is a new 
advancement in AR technology that using sensors in mobile devices, global positioning systems (GPS) and any part of the real environment to detect real world environments, such as location and intersection points that allow users to place virtual objects into real context without having to read images (Yih \& Chun, 2019).

\section{Development of the Augmented Reality Application}

The ADDIE framework is used in the development of the AR learning application (Rosset, 1987). This framework is systematic and organized, with few phases in the development of applications, systems, or software (Taufiq \& Aziz, 2018). Figure 1 represents the framework to design the learning application which consists of analysis, design, development, implementation, and evaluation.

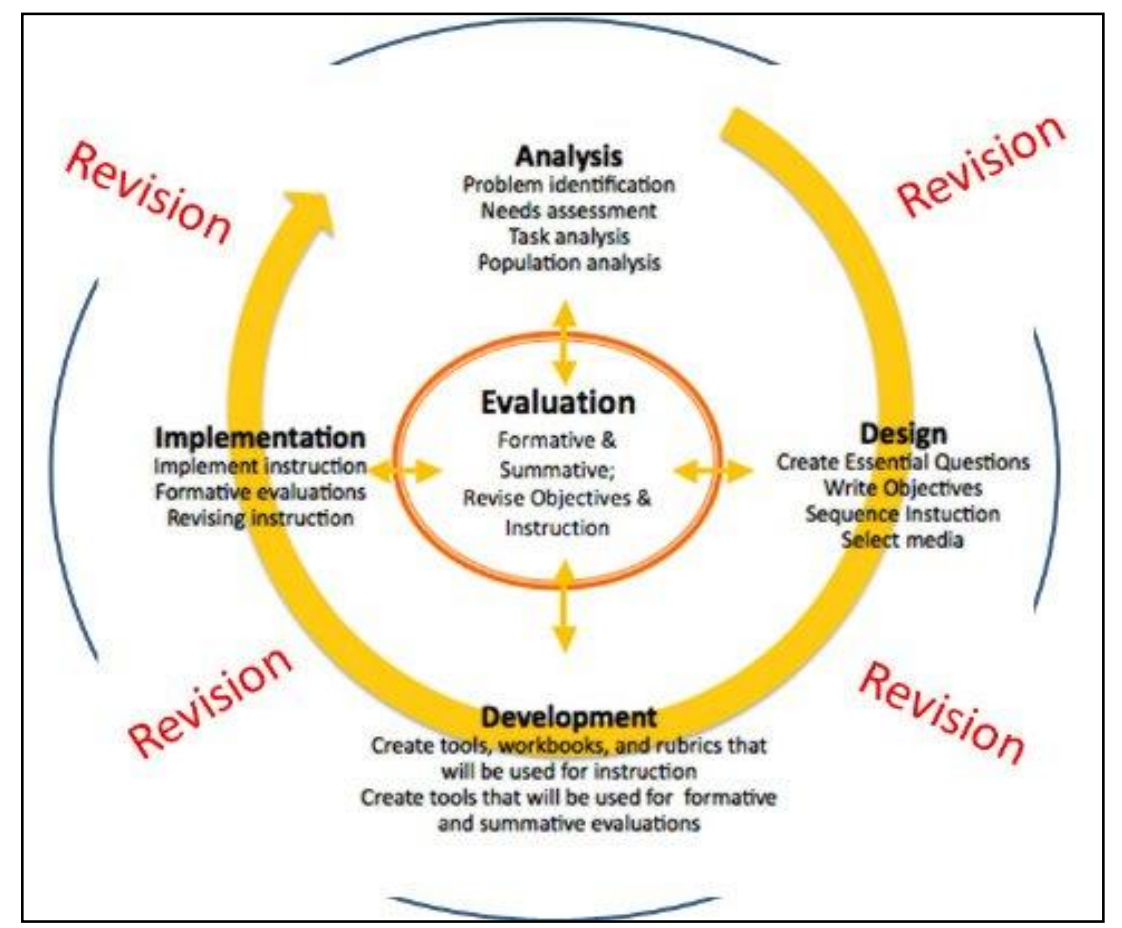

Figure 1: ADDIE Framework (Rossett, 1987)

\section{Analysis}

In identifying the problems faced by students in Shape and Space topics in mathematics and the need to develop this learning application, semi-structured interviews were conducted against three specialist teachers who taught mathematics education more than five years (Akbari \& Yazdanmehr, 2014; Berliner, 2004).

\section{Design}

The design is obtained from findings in the first phase of the analysis and identify the objectives that need to be achieved. The elements considered in this phase are such as teaching and learning methods, learning theory, learning objectives, learning activities, teaching and learning plans, teaching strategies, and media selection (Larson \& Lockee, 2014). In addition, it is important for researchers to create storyboard related to technical and visual design as well as multimedia elements such as text, images, animation, and video through storyboards. The designed storyboard will illustrate the overall display of the application. 


\section{DEVELOPMENT}

Vol. 11, No. 1, 2022, E-ISSN: 2226-6348 @ 2022 HRMARS

Figure 2 depicts a flowchart of the processes that will occur in the AR learning application's content structure.

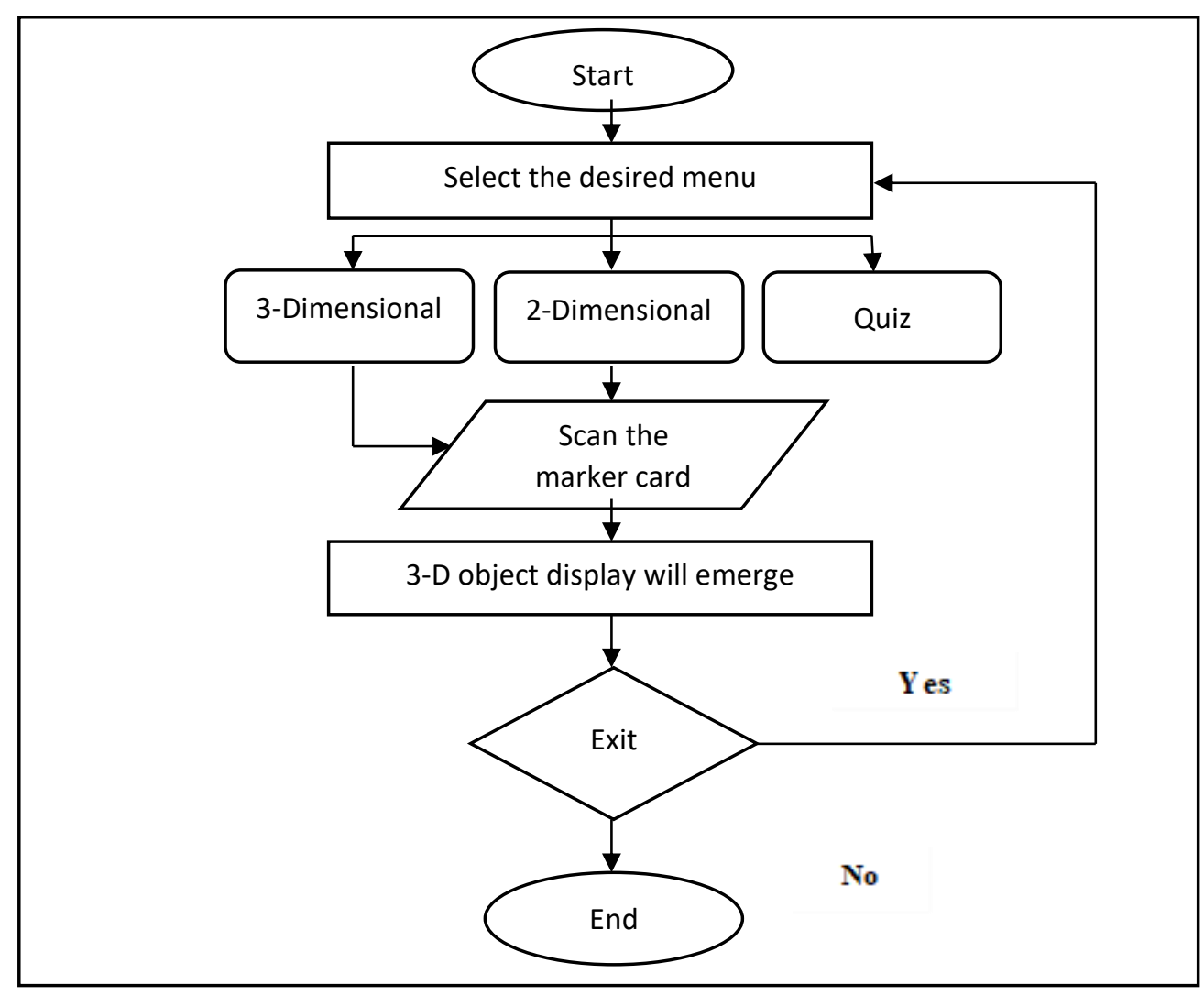

Figure 2: The flowchart of the AR Learning Application

\section{Development}

The development phase refers to the development of application prototypes. Multimedia elements such as the use of appropriate text and colour, the use of audio, image, animation, video, and graphics to ensure that the applications developed will have impact on student learning (Mahzan \& Othman, 2019). This study will use mobile and marker-based AR in learning process. Besides that, the alpha test of expert evaluation was conducted to determine the robustness of the application user interfaces and functionalities (Alessi \& Trollip, 2001). The purpose of alpha testing is to discover errors in the application before providing it to the end users. Meanwhile, a beta test entails evaluating the whole learning application produced and testing it on students to get feedback (Maccormack, 2001).

\section{Implementation}

Once the AR learning application and geometry test developed have been authenticated by experts and are ready to be utilized, it will be implemented to grade 2 students. It is a need to test the learning application and geometry test developed that can be used in the context of actual sample. The pilot study was given to 30 students to gain the reliability of the test.

\section{Evaluation}

The developed AR learning application would be examined for testing and evaluate the effectiveness on students' achievement for geometry topic based on the pretest and posttest. Therefore, the non-equivalent groups pretest-posttest design for quasi-experimental 
DEVELOPMENT

Vol. 11, No. 1, 2022, E-ISSN: 2226-6348 @ 2022 HRMARS

research design will used in this study. The data acquired from this evaluation is utilized to make decisions either the learning application developed is useful or ineffective via a quasiexperimental research at the end of the study. Table 2 represents the quasi-experimental design which will conducted in this study.

Table 2: Non-Equivalent Groups Pretest-Posttest Design

\begin{tabular}{|l|l|l|l|}
\hline Group & Pretest & Teaching Approach & Posttest \\
\hline Treatment & $\mathrm{O}_{1}$ & $\mathrm{X}_{1}$ & $\mathrm{O}_{2}$ \\
\hline Control & $\mathrm{O}_{3}$ & $\mathrm{X}_{2}$ & $\mathrm{O}_{4}$ \\
\hline $\mathrm{O}_{1}, \mathrm{O}_{3}$ & \multicolumn{2}{l|}{} \\
\hline $\mathrm{O}_{2}, \mathrm{O}_{4}$ & Geometry Topic Pretest \\
\hline $\mathrm{X}_{1}$ & Geometry Topic Posttest \\
\hline $\mathrm{X}_{2}$ & AR Application Teaching Approach \\
\hline
\end{tabular}

\section{Conclusion}

Research in the utilization of AR technology for the purpose of promoting primary school is still new. The development of AR application is targeted to the prospective primary school pupils to attract and gain the understanding on geometry topic. Since most of the pupils are using smartphone nowadays, the idea of developing the application coincides with the needs of pupils. It is hoped that the findings of this study will encourage more pupils to use the AR applications in understanding about geometry topic especially in 2D and 3D shapes. At the same time, it will help the teachers and Ministry of Education to introduce a new learning strategy using AR technology which is more creative, innovative, informative, usable, trending and up to date. Plus, this application will help pupils to achieve a good achievement in mathematics education and give a lot of benefits of using mobile in learning mathematics.

\section{Acknowledgement}

Thanks to School of Educational Studies from Universiti Sains Malaysia (USM) for providing the opportunity to complete this research according to targets and objectives.

\section{Corresponding Author}

Chew Ceng Meng

School of Educational Studies, Universiti Sains Malaysia

Email: cmchew@usm.my

\section{References}

Akçayir, M., Akçayir, G., Pektas, H. M., \& Ocak, M. A. (2016). Computers in Human Behavior Augmented Reality in Science Laboratories: The Effects of Augmented Reality on University Students' Laboratory Skills and Attitudes Toward Science Laboratories. Computers and Education, 57, 334-342. https://doi.org/f795v9.

Alessi, S. M., \& Trollip, S. P. (2001). Multimedia for Learning: Methods and Development. $3^{\text {rd }}$ Edition. Pearson.

Akbari, R., \& Yazdanmehr, E. (2014). A Critical Analysis of the Selection Criteria of Expert 
Teachers in ELT. Theory and Practice in Language Studies, 4(8), 1653-1658. https://doi.org/gn4f.

Azuma, R. T. (1997). A Survey of Augmented Reality. Teleoperators and Virtual Environments 6(4), 355-385. https://doi.org/gc2hkv.

Bahagian Perancangan dan Penyelidikan Dasar Pendidikan. (2020). Laporan Kebangsaan Trends in International Mathematics and Science Study (TIMSS) Tahun 2019. Kementerian Pendidikan Malaysia.

Berna, C. G. (2014). An Investıgation of Pre-Service Elementary School Teachers' Knowledge Concernıng Quadrilaterals. Gukurova University Faculty of Education Journal, 43(2), 137-154.

Berliner, D. C. (2004). Describing the Behavior and Documenting the Accomplishments of Expert Teachers. Bulletin of Science, Technology and Society, 24(3), 200-212. https://doi.org/d5gr.

Bressler, D. M., \& Bodzin, A. M. (2013). A Mixed Methods Assessment of Students' Flow Experiences During A Mobile Augmented Reality Science Game. Journal of Computer Assisted Learning, 29(6), 505-517.

Chang, H., Wu, H., \& Hsu, Y. (2013). Integrating a Mobile Augmented Reality Activity to Contextualize Student Learning of a Socioscientific Issue. British Journal of Educational Technology, 44(3), 95-99. https://doi.org/gn4h.

Chen, Y., Wang, Q., Chen, H., Song, X., Tang, H., Tian, M. (2019). An Overview of Augmented Reality Technology. Journal of Physics: Conference Series, 1237 (2), 022082. https://doi.org/g2sz.

Gunčaga, J., \& Žilková, K. (2019). Visualisation as a Method for The Development of the Term Rectangle for Pupils in Primary School. European Journal of Contemporary Education, 8(1), 52-68. https://doi.org/gn4k.

Gün, E. T., \& Atasoy, B. (2017). The Effects of Augmented Reality Elementary School Students' Spatial Ability and Academic Achievement. Education and Science, 42(191), 31-51. https://doi.org/gn4m.

Hendrayana, A., \& Wahyudin. (2018). Mobile Learning to Improve Mathematics Teachers' Mathematical Competencies. Journal of Physics, 948(1).

Ibáñez, M. B., Di, Á., Villarán, D., \& Delgado, C. (2014). Experimenting With Electromagnetism Using Augmented Reality: Impact on Flow Student Experience and Educational Effectiveness. Computers \& Education, 71, 1-13. https://doi.org/f5k62p.

Ibili, E., Çat, M., Resnyansky, D. S., \& Billinghurst, M. (2019). An Assessment of Geometry Teaching Supported with Augmented Reality Teaching Materials to Enhance Students' 3D Geometry Thinking Skills. International Journal of Mathematical Education in Science and Technology, 51(2), 224-246. https://doi.org/ghpqdn.

Law, J. S. C., \& Rosli, R. (2020). Pengetahuan Teknologi Maklumat dan Komunikasi Guru Matematik Sekolah Rendah. Malaysian Journal of Social Sciences and Humanities, 5(11), 71-84. https://doi.org/gn4n.

Kementerian Pendidikan Malaysia. (2017). Dokumen Standard Kurikulum dan Pentaksiran Matematik Tahap 1. KPM. Putrajaya.

Larson, M. B., \& Lockee, B. B. (2014). Streamlined ID: A Practical Guide to Instructional Design. New York: Routledge.

Li, W., Wang, J., Jiao, S., Wang, M., \& Li, S. (2019). Research on The Visual Elements of Augmented Reality Assembly Processes. Virtual Reality \& Intelligent Hardware, 1(6), 622-634. https://doi.org/gn4p. 
Lin, H. C. K., Chen, M. C., \& Chang, C. K. (2013). Assessing The Effectiveness of Learning Solid Geometry by Using An Augmented Reality Assisted Learning System. Interactive Learning Environments, 23(6).799-810. https://doi.org/gdxtk.

Maccormack, A. (2001). How Internet Companies Build Software. MIT Sloan Management Review. 42(2).75-84.

Mahzan, S. K., \& Othman, M. K. (2019). Pembangunan Sistem Prototaip E-Pendidikan Pondok di Kedah. International Journal of Education, Psychology and Counseling, 4(26), 1-26.

Mayer, R. E. (2009). Multimedia Learning. $2^{\text {nd }}$ Edition. Cambridge University.

Ministry of Education Malaysia. (2013). Malaysia Education Blueprint 2013-2025. Putrajaya. Kementerian Pendidikan Malaysia.

Milgram, P., Takemura, H., Utsumi, A., \& Kishino, F. (1994). Augmented Reality: A Class of Displays on The Reality-Virtuality Continuum. Telemanipulator and Telepresence Technologies, 2351, 282-292.

Mustafa Sirakaya \& Didem Alsancak Sikaraya. (2020). Augmented Reality in STEM Education: A Systematic Review. Interactive Learning Environments, 1-14. https://doi.org/gg2b3t.

Rossett, A. (1987). Techniques in Training and Performance Development Series: Training Needs Assessment. Englewood Cliffs, NJ: Educational Technology Publications.

Taufiq, A. G., \& Daud, A. A. (2018). Adaptation of ADDIE Instructional Model in Developing Educational Website for Language Learning. Global Journal Al-Thaqafah, 8(2), 7-16.

Yih, L. J., \& Chun, L. M. (2019). Aplikasi Augmentasi Realiti Interaktif untuk Reka Bentuk Dapur. Fakulti Teknologi \& Sains Maklumat, UKM. 